\title{
FULFILLMENT OF DECENT AND AFFORDABLE HOUSING NEEDS THROUGH THE AVAILABILITY OF PUBLIC FLATS \\ https://doi.org/10.47743/jopafl-2021-19-18
}

\author{
Trie SULISTIOWARNI \\ Faculty of Law, Brawijaya University, Malang, \\ East Java, Indonesia \\ sulistiowarni.fhub@outlook.com \\ Abdul Rachmad BUDIONO \\ Faculty Law, Brawijaya University, Malang, \\ East Java, Indonesia \\ Imam KOESWAHYONO \\ Faculty Law, Brawijaya University, Malang, \\ East Java, Indonesia \\ Setyo WIDAGDO \\ Faculty Law, Brawijaya University, Malang, \\ East Java, Indonesia
}

\begin{abstract}
Sustainable development and environment is development that meets the needs of the present generation without diminishing the opportunities for future generations to get a chance of life, with the goal of achieving ecological sustainability, economic, social, cultural, political, and defense and security. In fact, in an effort to meet people's need for affordable housing and residential areas for low-income people and to meet the demands of modern lifestyles, the government has always been faced with the problem of land limitations available for housing development, especially in densely populated urban areas. This is one of the obstacles in meeting the needs of public housing, resulting in a high number of housing backlogs in Indonesia, because the number of people who need a home is more than the supply of homes that can be provided in each year. Thus, strategic steps are needed that can be a breakthrough to overcome the housing backlog. This research is a legal research, a research by analyzing the rule of law and law based on dogmatic law, legal theory, and legal philosophy. The purpose of this study is to review Law No. 20 of 2011 on Flats, especially efforts to meet the needs of decent and affordable housing through the availability of public flats. As a regulator, the Government makes and prepares regulations and policies. Through various regulations issued by the Government is expected to be a solution in unraveling and addressing the problem of public housing and does not overlap, so that the target of meeting the needs of decent and affordable homes for MBR can be achieved.
\end{abstract}

Keywords: sustainable development, housing backlog, public flats.

\section{Introduction}

As the mandate of the Constitution which states that everyone has the right to live a prosperous life inwardly and outwardly, live and get a live environment that is viable and healthy, the state is responsible for the implementation of the housing and settlements for the people. In order to carry out these responsibilities, the state is obliged to meet the needs 
of a decent place of residence for all people, as the fulfillment of the civil and political rights, economic, social and cultural rights of each of its citizens, of which these rights are attached to man as a natural right, contained in the International Covenant on Economic, Social, and Cultural Rights set forth in The United Nations General Assembly resolution 2200 A (XXI) dated December 16, 1966 (Kurniati, 2014). Furthermore, the International Covenant on Economic, Social and Cultural Rights by the Republic of Indonesia has been ratified through the establishment of a law that ratifies it (Law Number 11 of 2005 concerning Ratification of the International Covenant on Economic, Social and Culture Rights). In addition, Indonesia has also ratified the International Covenant on Civil and Political Rights with a law specifically made to ratify it. The hope of the community with the ratification of the two covenants is that there is a guarantee of legal certainty and justice for upholding their human rights, especially in fulfilling the need for livable housing which is the government's obligation to fulfill it. Ideally, every family should have an adequate place to live, especially for low-income families and people who live in densely populated urban areas. But in reality, with various obstacles and problems as discussed in the previous chapter, the housing backlog figure is still high. This means that there are still very many families, especially the low-income group, who do not live in proper housing or do not have houses. This is where the role of the government as state administrator is needed in maintaining the continuity of housing provision to meet the needs of adequate housing for all people, as a form of state responsibility in fulfilling citizens' rights, especially in the housing sector.

\section{Legal materials and method}

This research is a legal research, which is a research that is carried out by examining the rules and laws that apply to answer the legal problems under study (Ibrahim, 2012). Legal research is a research by analyzing legal rules and laws based on dogmatic law, legal theory, and legal philosophy (Marzuki, 2011). The normative side that will be studied is Law Number 20 of 2011 concerning Flats, especially efforts to fulfill the need for decent and affordable housing through the availability of public flats. As a legal research with the obligation to provide public flats by the State in the Flat Law, this study uses several approaches in order to understand legal issues more holistically. As a legal researcher with the obligation to provide public flats by the State in the Bill, this study uses several approaches in order to understand legal issues holistically. First, the approach of legislation (statute approach) (Soekanto, 1998), namely by reviewing and researching the legislation related to consistency between the basic constitution of the 1945 Constitution, and several laws and other legal rules related to flats. Second, conceptual approach, which is an approach by studying and studying the doctrines or principles of law that can be used as a basis in solving legal problems faced.

\section{Results and discussion}

\section{The Government's Role in Housing Management}

In the implementation of housing the role of the government is as a regulator, facilitator and operator. 


\section{Government's Role as a Regulator}

As a regulator in the implementation of public housing, the government has a role in making / issuing a variety of regulations related to the implementation of public housing, ranging from the formation of laws, government regulations, ministerial regulations, and local regulations, because the implementation of public housing is not only the domain of the central government, but also includes local governments. In carrying out its role as a regulator in the implementation of public housing, the government continues to strive for the growth of the housing sector, especially in housing development for MBR is maintained. As it is formulated in 5 (five) strategies in dealing with the challenges of housing development outlined in the National Long-Term Development Achievement (RPJPN) 2005-2025. These five strategies are guidelines used as guidelines and directives in making regulations in the field of housing and settlements including the regulation of flats. The first strategy includes tax reform, regional licensing levy, land and spatial planning. The second strategy is to improve the pattern of housing subsidies. The third strategy encourages tax incentives for the business world. The fourth strategy is to provide housing microcredit facilities and community empowerment through the technical assistance of community groups. The fifth strategy is the provision of housing that takes into account a variety of factors, not limited to just the purchasing power factors of the community (Winayanti, 2017). Based on the strategy as outlined above, related to the provision of assistance in the form of ease of housing financing for MBR, the government has issued several policies, namely KPR-FLPP (Housing Financing Liquidity Facility) and SSB (Interest Difference Subsidy), as the authors discussed in the previous chapter, SBUM (Down Payment Assistance Subsidy) for MBR, as well as the provision of low-interest mortgage loans through the FLPP scheme and the freedom to determine down payments for banks. In addition, the Government of the Ministry of Finance has issued a regulation on Simple House Price Restrictions that is exempt from the imposition of Value Added Tax (VAT). In an effort to support the success of housing development, especially decent homes for MBR, in addition to acting as a regulator, the government also carries out the task of accelerating. Related to this, there are three accelerators that also have an important role in the development of the housing sector, namely the Financial Services Authority (OJK) through banking regulation and consumer protection, both of which bank Indonesia, related to credit growth policy through Loan To Value (loan size compared to the value of property used as collateral), and the third Government, through fiscal policy, incentives and transactions (Mardiasmo, 2018). As a regulator, various regulations issued by the Government can be a solution in unraveling and addressing the problem of public housing and does not overlap, so that the target of meeting the needs of decent and affordable homes for MBR can be achieved.

\section{Government's Role as a Facilitator}

In the implementation of housing, in addition to being a regulator, the Government also serves as a facilitator that facilitates the provision of housing and settlements for the community, especially for MBR, and facilitates the implementation of policies and strategies at the national level (Article 13 letters g and $\mathrm{h}$ "Law on Housing and Settlement Areas (Perkim)"). Community involvement in the development of public housing is the widest right and opportunity to participate in the implementation of housing, as it is 
provided by law, based on the Settlement Law and the Flats Law. With the granting of rights and opportunities for the community in the implementation of housing by the laws governing the field of housing as stated above, the Government by the laws governing housing is given the task to act as a facilitator with the main task of facilitating the provision of housing and settlements for the community, especially low-income people. The task of facilitating this includes providing incentives to development actors and ease for MBR in obtaining decent homes/flats by providing financing assistance through Home Ownership Loans under the Housing Financing Liquidity Facility (FLPP) scheme, Interest Difference Subsidy (SSB), and Housing Advance Assistance (BUMP), as reviewed and outlined in the previous chapter. This is in accordance with the politics of legislation in the field of housing (Settlement Law and Flats Law) that shows the state's impartiality to low-income people. With the spirit of the implementation of regional autonomy as the provisions of the prevailing laws and regulations, as well as the emergence of housing problems that are no longer centralized and more likely to be oriented in exploring and developing the capabilities of local communities, the role of the Government as a facilitator in the implementation of housing is implemented decentralized, in accordance with the demands of autonomy in the implementation of housing. In terms of the provision of land for the construction of housing both tread houses and flats, in addition to the release of land rights, can be done by utilizing the former land of abandoned land or through a mechanism of land consolidation involving landowners whose land will be used as objects of land consolidation (Regulation of the Minister of Agrarian Affairs and Spatial Planning / Head of the National Land Agency of the Republic of Indonesia Number 12 of 2019 concerning Land Consolidation, State Gazette of the Republic of Indonesia of 2019 Number 756. Article 1 number 1). Given that in the mechanism of land consolidation where in its implementation will involve the active participation of landowners as participants of land consolidation, it is expected that through the role of the Government as a facilitator can empower the community, especially MBR landowners to participate in the provision of housing. In addition to the main task of facilitating the provision of decent homes for MBR, as a facilitator the Government has the task of facilitating the implementation of policies and strategies at the national level. At the provincial level, in addition to the task of facilitating the provision of homes for MBR, the Provincial Government facilitates the management of housing and residential areas at the provincial level, and facilitates the implementation of policies and strategies at the provincial level. While the District / City Government only has the task of facilitating the provision of housing and settlements for the community, especially MBR. In the implementation of flats, the Government has the task of facilitating the provision of flats for the community, especially MBR, facilitating the provision of PSU for flats provided for MBR (public flats), which is the same task as the duties of the Provincial Government. As for the Regency/City Government, in addition to the same tasks as the Government and Provincial Government above, as a facilitator of the implementation of flats, the Regency/City Government also has a duty to facilitate the maintenance and maintenance of PSU built independently by the community. The government in its role as a facilitator acts to facilitate the activities covered by housing management based on its duties and authorities according to the level of authority. Therefore, besides having the task of facilitating as described above, the Government also acts to facilitate based on the authority as stipulated in the Law on Settlement and the Law on Flats. Based on the authority they have, the Government and Regional Governments 
(Provinces and Regencies / Cities) facilitate cooperation between the Government and legal entities in the management of housing (implementing housing and residential areas and administering flats) at the level according to their authority, facilitating the improvement of the quality of slum housing and settlements. slum, facilitating the management of housing and residential areas PSU (the authority to facilitate landed houses), facilitating the improvement of the quality of public flats, special flats and state flats and facilitating the management of common parts and common objects in public flats, special flats and flats state (authority to facilitate for flats). Another action that must be taken by the Government in its role as facilitator in housing management, particularly in the management of flats, is to facilitate several activities related to providing incentives to actors in the construction of public and special flats. The provision of incentives referred to is facilitation in land acquisition, facilitation of the land certification process, facilitation in the licensing process and facilitation of construction loans with low interest rates (Article 88 paragraph (2 letters a, b, c, d) "Law on Flat Houses (Flats)").

\section{Government's Role as Operator}

As the operator of housing management, the Government carries out the function of operationalization and coordination of the implementation of national policies on the provision of houses and development of residential areas and residential areas and allocates funds and / or development costs to support the realization of decent and affordable housing for low-income families (Article 13 letters e and f "Perkim Law"). Meanwhile, in the management of flats, the role of the government as an operator is to carry out the operational function of implementing the policy on the provision of flats and developing the apartment environment as part of the national level settlement (Article 13 letters e and $f$ "Perkim Law"). Likewise, as the operator of the management of flats, the Government and Regional Governments are obliged to meet the needs of public flats for MBR through the provision of assistance and / or ease of construction of public flats with funding support originating from the APBN / APBD and or other funding sources (Article 13 letters e and f "Perkim Law"). In carrying out their obligations in fulfilling the needs of the apartment suitable for MBR, the Government and Local Government undertake the construction of flats, finance the program to provide easy acquisition of flats for MBR, carry out maintenance To support development activities and provide facilities for MBR as mentioned above, the Government and / or Local Governments undertake efforts to develop a financing system which includes the development of financing institutions (Elucidation of Article 91 paragraph (1) "Flat Law"), mobilizing and accumulating funds, utilizing sources of costs and facilities or financing assistance.and maintenance of flats and carry out construction in order to improve the quality of flats (Articles 94 and 95 "Flat Law"). Efforts to accumulate funds and develop a financing system are necessary to ensure the availability of long-term low-cost funds and funds, so that the availability of adequate housing and flats for MBR can be guaranteed.

Government Efforts to Fulfill the Needs for Adequate Housing for MBR through the Availability of Public Flats

One of the ways to improve the standard of living for low-income people is if they occupy or live in a decent shelter with a healthy and safe living environment. Particularly in urban areas, the need for decent and affordable housing for low-income families at this 
time can only be met through the provision of public flats, because the availability of land is increasingly limited and the price is very expensive so that the purchasing power of MBRs cannot. Facing such a situation, the Government, which has the obligation to meet the needs of decent housing for low-income families as mandated by the constitution, has made various efforts so that the need for proper housing can be met through the availability of public flats. The Government's efforts were made in accordance with its role as regulator, facilitator and operator in the operation of flats. By increasing the efficiency of land use, the construction of decent and affordable public flats can be built on land located in the middle of the city, which makes it easier for low-income residents who live in flats to get closer to the center of their daily activities. Besides that, the existence of flats as a proper place to live can prevent the emergence of slum areas in urban areas, increase the capacity of low-income families who require proper housing, increase mobility with the ease of public transportation, all of which have a positive impact on increasing community productivity. In an effort to meet the needs of public flats in urban areas, both the Government and the Regional Government as the operator of the apartment management have built several simple rented flats (rusunawa), and as a regulator, through various regulations made, the Government makes it easy for MBR to obtain a house stacking feasible. Likewise, in their role as facilitator, the Government and / or local governments facilitate development actors / developers by providing various incentives to increase developers' interest in providing simple flat owned (rusunami) that can be owned by MBR. With the availability of public flats located in the middle of the city, it is hoped that the former MBR due to limited purchasing power will only be able to live in the suburbs far from his workplace. In such conditions, of course, people need large transportation costs and long travel times to carry out their mobility, which results in decreased community productivity. Meanwhile, for people whose homes are close to their economic activities, but who do not occupy proper housing, this can trigger the emergence of slum areas and cause irregular urban spatial planning. To answer the problem of public housing, especially in urban areas, the Government has made various efforts so that the needs for proper housing for the community, especially for low-income families, can be met.

\section{Provision of Land for the Construction of Simple Rental Flats (Rusunawa) by the Government}

In building a flat, land is an important main factor because it is related to fulfilling the legality requirements which form the basis of the status of land ownership rights on which the apartment is built. Likewise, land that is used for the construction of a flat that is built by the Government and or the Regional Government, where in accordance with the provisions in the Flat Law on the land concerned, a certificate of land rights must be issued. Based on the provisions of the prevailing laws and regulations, land obtained by the Government can be given a right to use. Land that is used to build a flat can come from land / land acquisition or from utilizing land which is an asset of State Property or Regional Property. The construction of public flats with lease status according to statutory provisions is one of the categories of development for the public interest, which is a development effort in the framework of national development organized by the Government and used for the prosperity of the people (Article 1 point 6 Law Number 2 Year 2012 concerning Land Acquisition for Development for Public Interest. Public Interest is the interest of the nation, state and society which must be realized by the government and used maximally 
for the prosperity of the people). Since the development of a flat is included in the development for public interest, the provision of land must be carried out by the Government and / or the Government, where the procurement procedure is carried out according to the land acquisition mechanism regulated in the law in the field of land acquisition for development for public interest, and carried out while ensuring legal interests of the owner / holder of land rights. For the purposes of land acquisition, the Government and / or the Regional Government shall guarantee the availability of funding.

The Allocation of Funds for the Development of Rusunawa which comes from the APBN / $A P B D$

The public housing problem which is felt to be increasingly critical and serious with the increasing number of the national housing backlog, not only requires serious attention, but the government must be present in the effort to overcome these problems. The imbalance between housing needs for the community, especially for low-income housing, with the ability of the government and developers to provide it, which according to estimates by the Ministry of PUPR only ranges from 30\% -40\% per year of the total number of housing units needed annually, causing a rapid increase in the housing backlog (Pakpahan, 2015). To fulfill the constitutional mandate and based on the prevailing laws and regulations, especially those regulating the housing sector, the Government has prepared a number of budget policy scenarios in order to reduce the housing backlog figure, one of which is through budget allocation for the construction of flat-houses whose source of funds comes from APBN / APBD.

\section{Providing Convenience for Low-Income Communities through Housing Financing}

The high need for houses which is not followed by the community's ability to own them due to their low income, requires the role of housing finance as an effort for citizens to build or own a house, by dividing the cost of buying or building a large enough house into a longer time period so that the community as a home buyer can adjust the burden according to their financial capacity (Coordinating Ministry for People's Welfare, 2012). If for the construction of rusunawa the role of the Government in the provision of houses for MBR is to build rusunawa, then in the construction of prosperous sites and rusunami houses the Government provides convenience for MBR in obtaining home ownership through housing financing programs. In the housing finance system, there are several parties involved, namely, developers who provide housing supplies, financial institutions that provide financing, and the Government as regulators and supporters. The important role of housing finance is partly due to the high price of the house so it is only natural that the purchase of a house is financed with a loan. Another important point is that no government in the world can meet all the housing needs of its citizens (Directorate General of Budget, Ministry of Finance of the Republic of Indonesia, 2015). In Indonesia, the housing financing scheme used by the public in general is through Home Ownership Credit (KPR), which is a credit product (financing) from banks that buy houses or for other consumptive needs with collateral in the form of a house (Sari, 2013). In terms of target borrowers, there are two types of KPR, namely subsidized KPR aimed at MBR based on Government policy, and non-subsidized KPR aimed at the entire community, either through conventional financing schemes or sharia financing schemes. The amount of financing provided by the Bank through KPR cannot reach $100 \%$ of the house price. 
Housing financing in Indonesia has been started several years ago through the role of the Government with the establishment of the National Housing Development Public Company (Perum Perumnas) in 1974, which was given the responsibility of providing housing for MBR, followed by the formation of the State Savings Bank (BTN) to distribute credit or housing finance for low-income households in obtaining decent and affordable housing (Suparwoko, 2013). With the launch of the national program for the construction of a million houses, the Government has accompanied the program by launching a subsidized KPR program with the Interest Difference Subsidy (SSB) and Advance Assistance Subsidy (SBM) schemes. This subsidized KPR program was further developed with a new pattern currently in effect known as the KPR Sejahtera, the Housing Financing Liquidity Facility (FLPP). FLPP is a program provided by the Government in the form of revolving funds intended for financing KPR Sejahtera Tapak (for simple houses) and KPR Sejahtera Susun (for simple-owned flats) and subsidized Sharia mortgages for Sharia-based housing financing. In addition to financing based on the FLPP, SSB and SBM mortgage schemes, the Government also provides housing financing facilities with the SavingsBased Housing Financing Assistance (BP2BT) scheme. BP2BT is the implementation of the World Bank's National Affordable Housing Program (NAHP) in which the World Bank provides housing support funding loans to the Government which is one form of actualization of the State Partnership Framework (K3N). BP2BT program scheme is a government assistance program provided to MBR who have had savings in order to fulfill part of the down payment on the acquisition of a house or part of the down payment for the acquisition of a house or part of the funds for the construction of a self-help house through credit or financing of the implementing bank (PUPR Ministerial Decree 858 / KPTS / M / 2017 concerning Savings-Based Housing Financing Assistance).

\section{Establishing Partnerships Through Cooperation Between Government and Business Entities (PPP) in Rusunawa Development}

The need for a high budget to suppress housing backlog figures has so far not been addressed due to the limited capacity of the Government's budget. Therefore, the Government through the Ministry of PUPR initiates by seeking to encourage private involvement in the construction of flats through various models of cooperation between the Government and Business Entities (PPP). This is done because not all the needs of public flats can be met alone by the Government, because of the limited source of funds from the State Budget / APBD, therefore, alternative innovation of non-APBN / APBD financing through ppp scheme that is currently being offered to business entities, both stateowned enterprises / BUMD and private business entities. PPP is a non-APBN creative financing, which is necessary to overcome the release of the Government's budget in the implementation of decent housing for MBR by involving private sector participation in housing supply investment (especially rusunawa or rusunami) by utilizing Governmentowned land on the basis of cooperation agreements made between the government and business entities. To support the partnership program with the PPP scheme, the Ministry of PUPR has established a new Directorate called the Directorate General of Public Works and Housing Infrastructure Financing, whose task focuses on the development of non-apbn financing models such as non-budget government investment financing (PINA) or PPP (Handoyo, 2019). 
Construction of Flats with Transit Oriented Development (TOD) Residential Concept

To solve the problem of public housing, not only meet the needs of residential buildings and their environment, but must include the fulfillment of the need for ease of mobility in carrying out their socioeconomic activities. Providing public flats that are located far from the center of the crowd and economic activities in fact do not solve the housing problem because the community is not interested in inhabiting flats built in locations that are not strategic. Understanding the needs of the community that not only fulfills the availability of housing, the Government in its series of efforts to ensure the fulfillment of decent and affordable housing in dense urban areas, as well as to reduce the number of housing backlogs, has developed the concept of TOD housing, namely building flats that are integrated with public transportation facilities. This concept is a merger of residential and commercial areas in one area designed to maximize residents' access to public or public transportation, such as trains (commuter lines), mass rapid transit (MRT), light rail transit (LRT), and busways. The type of property built with the concept of TOD occupancy is vertical occupancy. This is because given the limited land in major cities, where for the property segment in addition to intended for people with middle and upper economic levels, also as much as 20-30 percent occupancy for middle-income people and lower (MBR criteria). The construction of flats with the concept of TOD allows people who inhabit flats can be easier in carrying out their activities to meet their daily needs, as well as to accessibility facilities, so as to save costs for transportation. Currently the Government in this case the Ministry of PUPR in synergy with the Ministry of SOEs is building 6 (six) TOD residential projects, 5 (five) locations in Jakarta, namely TOD Manggarai, TOD Tanah Abang, TOD Senen Station, TOD Tanjung Barat, TOD Pasar Jumat, and 1 (one) location in Depok, namely TOD Pondok Cina. All residential flats are integrated with Train/Electric Railway (KRL) stations, MRT stations and transjakarta buses. Tod residential development will continue to South Tangerang, Bogor and Bandung.

\section{Conclusion}

As a form of state responsibility in the fulfillment of the rights of citizens, especially in the field of housing, the Government as the state organizer has an important role in maintaining the continuity of housing provision to meet the needs of decent housing for the entire community. These roles include the role of regulator, facilitator and operator. Through its role, the Government has made various efforts so that the fulfillment of the needs of decent and affordable homes for MBR can be met in accordance with the target planned in the RPJMN 2020-2024. As a regulator, the Government makes and prepares regulations and policies. Through various regulations issued by the Government is expected to be a solution in unraveling and addressing the problem of public housing and does not overlap, so that the target of meeting the needs of decent and affordable homes for MBR can be achieved. As a facilitator, the Government provides incentives to development actors and ease for MBR in obtaining decent homes/flats by providing financing assistance through Home Ownership Loans under the Housing Financing Licwidity Facility (FLPP), Interest Difference Subsidy (SSB), and Housing Advance Assistance (BUMP). As the operator of the implementation of flats, the Government and Local Government are obliged to meet the needs of public flats for MBR by carrying out 
the construction of flats, financing the program of providing ease of acquisition of flats for MBR, maintaining and maintaining flats and carrying out development in order to improve the quality of flats. In carrying out the construction of public flats, both the Government and Local Government also seek to involve the private sector or business entities by establishing partnerships through the Government Cooperation with Business Entities (PPP) scheme. To support development activities and provide convenience for MBR as stated above, the Government and or Local Government conduct financing system development efforts that include the development of financing institutions, the deployment and fertilization of funds, utilizing the source of costs and ease or financing assistance.

\section{References}

1. Coordinating Ministry for People's Welfare. (2012). Kesejahteraan Rakyat Atas Papan: Akselerasi Pemenuhan Kebutuhan Papan, Jakarta: Kemenkokesra.

2. Directorate General of Budget, Ministry of Finance of the Republic of Indonesia. (2015). Peranan APBN Dalam Mengatasi Backlog Perumahan Bagi Masyarakat Berpenghasilan Rendah (MBR).

3. Handoyo. (2019). Kementerian PUPR jajaki pembangunan rusun dengan skema KPBU. (online) http://nasional.kontan.co.id/news/kementerian-pupr-jajaki-pembangunan=rusun-dengan-skema- $\quad$ kpbu accessed on Oktober, 122020.

4. Ibrahim, J. (2012). Teori dan Metode Penelitian Hukum Normatif. Malang, Bayumedia.

5. Kurniati, N. (2014). Pemenuhan Hak Atas Perumahan dan Kawasan Permukiman yang Layak dan Penerapannya Menurut Kovenan Internasional tentang Hak-hak Ekonomi, Sosial dan Budaya di Indonesia. Pajajaran Jurnal Ilmu Hukum, 1(1), 78-98. DOI: https://doi.org/10.22304/pjih.v1n1.a5

6. Lupu, D. (2019). Cost-benefit analysis for transport infrastructure projects: Eastern european cases. Journal of Public Administration, Finance and Law, (15), 107-123.

7. Mardiasmo. (2018). Perpajakan Edisi Revisi Tahun 2018. Yogyakarta: Penerbit Andi.

8. Marzuki, P.M. (2011). Penelitian Hukum. Jakarta, Kencana Prenada Media Group.

9. Pakpahan, Deddy H. (2015). The Three Musketeers: Solusi Atasi Backlog Perumahan Di Indonesia (online), http://jktproperty.com/three-musketeers-solusi-atasi-backlog-perumahan-di -indonesia accessed on Oktober, 102020.

10. Soekanto, S. (1998). Pengantar Penelitian Hukum. Jakarta, Universitas Indonesia Press.

11. Suparwoko. (2013). Peningkatan Kapasitas Perumahan Swadaya Di Indonesia. Yogyakarta, Total Media.

12. Winayanti, L. (2017). Sinergi Antara Regulator, Perbankan, Pengembang Dalam Meningkatkan Pertumbuhan Kredit dan perlindungan Konsumen di Sektor Property. National Seminar on InfobankBanking, Property \& Mortgage Summit, Jakarta 16 May 2017.Sari, P.P. (2013). Perbandingan Kredit Kepemilikan Rumah Pada Bank Konvensional Dengan Pembiayaan Kepemilikan Rumah Pada Bank Syariah. Jurnal Akuntansi Unesa, 1(2), 1-20. $\quad$ Available https://jurnalmahasiswa.unesa.ac.id/index.php/jurnal-akuntansi/article/view/724/508

13. Indonesia, Law Number 11 of 2005 concerning Ratification of the International Covenant on Economic, Social and Culture Rights (International Covenant on Economic, Social and Cultural Rights, State Gazette of the Republic of Indonesia Number 118, Supplement to the State Gazette of the Republic of Indonesia Number 4557.

14. Indonesia, Law Number 12 of 2005 concerning the Ratification of the International Covenant on Civil and Political Rights, Le, the Republic of Indonesia of 2005 Number 119, Supplement to the State Gazette of the Republic of Indonesia Number 4558.

15. Indonesia, Law of the Republic of Indonesia Number 1 of 2011 concerning Housing and Settlement Areas

16. Indonesia, Law Number 2 of 2012 concerning Land Acquisition for Development for Public Interest. 
17. Indonesia, PUPR Ministerial Decree 858 / KPTS / M / 2017 concerning Savings-Based Housing Financing Assistance.

18. Indonesia, Regulation of the Minister of Agrarian Affairs and Spatial Planning / Head of the National Land Agency of the Republic of Indonesia Number 12 of 2019 concerning Land Consolidation, State Gazette of the Republic of Indonesia of 2019 Number 756.

19. Indonesia, Law Number 20 of 2011 concerning Flats. 